\title{
Sujeitos do Diálogo: abordagem e implicações a partir da Teologia Católica
}

\author{
Dialogue Subjects: \\ approach and implications from Catholic Theology
}

Éverton Aparecido da Silva

\section{Resumo}

O diálogo consiste numa atitude espontânea em busca do encontro dos diferentes capaz de gerar frutos de uma experiência gratuita onde a beleza e o encanto do outro aproxima e cativa. Ao cristão, cabe ficar atento às necessidades e possibilidades do diálogo, é pré-condição para abertura ao pluralismo eclesial e religioso. As possibilidades de crescimento por meio do diálogo são inúmeras e legítimas. Sob a ótica de uma Teologia que preze pelo diálogo como mediador de aprendizagens significativas e da ressignificação das interações na troca diária de conhecimentos construídos mutuamente, acena-se como objetivo a relação dialogal como paradigma do agir cristão, promovendo a participação ativa dos agentes pastorais, ministros ordenados ou não, da Igreja Católica. A identidade do sujeito eclesial possui uma configuração relacional, que se dá com sua comunidade, na sociedade e com as diferentes tradições eclesiais e religiosas. Jesus é modelo de escuta, diálogo e anúncio, é o referencial na busca de estabelecer o diálogo no encontro com o outro. Com o Vaticano II se redescobre a beleza de ser a Igreja que Jesus formou para evangelizar o mundo. O diálogo como paradigma do agir cristão possui como fim a unidade do Povo de Deus.

Palavras-chave: Sujeitos. Diálogo. Teologia Católica. 


\begin{abstract}
The dialogue consists of a spontaneous attitude in search of meeting the different, capable of generating the fruits of a free experience where the beauty and charm of the other approach and captivate. It is up to the christian to be attentive to the needs and possibilities of dialogue, is a precondition for opening to ecclesial and religious pluralism. The possibilities for growth through dialogue are numerous and legitimate. From the perspective of a Theology that values dialogue as a mediator of meaningful learning and the reinterpretation of interactions in the daily exchange of mutually constructed knowledge, the objective is to establish a dialogical relationship as a paradigm of christian action, promoting the active participation of pastoral agents, ordained or not ordained ministers of the Catholic Church. The identity of the ecclesial subject has a relational configuration, which occurs with his community, in society and with the different ecclesial and religious traditions. Jesus is a model of listening, dialogue and announcement, he is the reference in the search to establish dialogue in the encounter with the other. With Vatican II the beauty of being the Church that Jesus formed to evangelize the world is rediscovered. Dialogue as a paradigm of christian action aims at the unity of the People of God.
\end{abstract}

Keywords: Subjects. Dialogue. Catholic Theology.

\title{
Introdução
}

O diálogo é um elemento inerente à condição humana. Está presente na constituição da identidade dos indivíduos e na realização de sua sociabilidade. É um atributo singular de cada membro da sociedade, mas principalmente, uma característica capital das relações sociais. Deve ser o conteúdo e a grande ferramenta das ações pedagógicas na instauração de uma nova cultura para os ambientes formativos que promovam a reflexão da condição do ser humano contemporâneo.

No Ocidente, o diálogo constitui uma aquisição fundamental legada do pensamento grego. Com base na etimologia grega do vocábulo diálogo, é importante ressaltar a presença de dois termos: 'dia' e 'logos'. A expressão ' logos' cobre uma vasta gama de significados, mas indica em particular o dinamismo racional do ser humano, a capacidade humana de pensamento e 
raciocínio. O termo 'dia' expressa dupla ideia: refere ao que separa e divide, mas igualmente à ultrapassagem de um limite.

O diálogo amplia a visão e possibilita mudança de ponto de vista, possibilita reavaliação das suposições. "Embora se desenvolva a partir de pontos de vista diferentes, o verdadeiro diálogo supõe um clima de boa vontade e compreensão recíproca". ${ }^{1}$ É um aprendizado progressivo, exige discernimento, articulação, opção e decisão até assumir forma expressiva de conteúdo, linguagem, conduta.

De acordo com a concepção sociológica, "o ser humano é um nó de relações, não podendo ser compreendido de forma destacada do outro com o qual se comunica. O diálogo constitui, assim, uma dimensão integral de toda a vida humana". ${ }^{2} \mathrm{O}$ diálogo efetivo é um pré-requisito absolutamente essencial para discussões produtivas. Diálogo é uma estratégia sine qua non para se construir um mundo mais humano.

Para Sócrates, ${ }^{3}$ o diálogo é visto como um princípio filosófico que ajuda a entender a filosofia, não como algo abstrato, mas como algo que faz parte da vida e o faz de uma forma muito concreta, pois lida com questões essenciais da existência humana. Todos nós descobrimos, em algum momento de nossas vidas, através de questões filosóficas, questões diretamente conectadas com nossa existência. ${ }^{4}$

Sob a ótica de uma Teologia que preze pelo diálogo como mediador de aprendizagens significativas e da ressignificação das interações na troca diária de conhecimentos construídos mutuamente, acena-se como objetivo a relação dialogal como paradigma do agir cristão, promovendo a participação ativa dos sujeitos, agentes pastorais, ministros ordenados ou não, da Igreja Católica, especialmente no Brasil, que transita por uma fase governamental não confiável na dialogicidade.

\footnotetext{
${ }^{1}$ DUROZOI, G. D.; ROUSSEL, A., Diálogo, p. 135.

2 TEIXEIRA, F.; DIAS, Z. M., Ecumenismo e diálogo inter-religioso, p. 124.

${ }^{3}$ A exemplo de Sócrates, surge no século XX, um filósofo norte-americano, Matthew Lipman, que enfatiza não o ensinar filosofia, mas o fazer filosofia e ali o diálogo regido pela lógica é a essência, o coração da filosofia. O diálogo mostra que a filosofia foi pensada por pessoas em situações concretas, então não nos tira da realidade, mas nos leva a enfrentar problemas inerentes à existência, pois tem como pano de fundo a vida humana e é capaz de interrogá-la. É justamente com o diálogo que ocorre da pessoa ser indagada em relação à vida e aos demais humanos.

${ }^{4}$ Neste pensamento, o francês Emmanuel Levinas (1906-1995), filósofo da alteridade, baseia também seu axioma na relação com o outro, é no face-a-face humano que se brota todo sentido. $\mathrm{O}$ "eu" precisa se abrir para o outro, em especial para o que o outro me apresenta de diferente, que merece ser respeitado exatamente como se encontra, sem indiferença pelas suas particularidades.
} 
O diálogo enquanto ferramenta mediatizadora abre possibilidades para o desenvolvimento da autonomia uma vez que, o ser humano no momento em que passa a questionar e encarar o conhecimento não como algo pronto e acabado, mas, como algo passível de problematizações, estabelece, a partir de sua condição autônoma, critérios de resoluções típicos de seres pensantes num exercício autorreflexivo constante.

As possibilidades de crescimento por meio do diálogo são inúmeras e legítimas, uma vez que é na comunicação e na interação com o outro que o ser humano se constitui enquanto ser racional. A comunicação é uma propriedade específica da espécie humana. Comunicamo-nos para transmitir informações através da materialização verbalizada dos nossos pensamentos direcionados sempre para um interlocutor. Essa comunicação não se dá no vazio ou de forma solitária, uma vez que, a finalidade do ato comunicativo é justamente a de estabelecer uma relação dialógica entre quem fala, locutor, e quem escuta, interlocutor, e isso implica dizer que os sujeitos que se comunicam são os mesmos sujeitos que pensam e que pretendem repassar tal pensamento para o outro, seu interlocutor.

De uma forma mais direta, não há diálogo fora da interação, visto que interagimos através do diálogo. Ao adotar essa estreita relação, reconhece-se, também, que a falta de um pressupõe a não existência do outro. Não há como negar a relevância do diálogo nas mais variadas situações de interação humana. Contudo, o diálogo tem seu espaço comprometido em virtude de algumas posturas que o despreza.

O pluralismo religioso e eclesial é considerado como um autêntico sinal dos tempos na realidade atual. São muitas as situações e ambientes em que se vive e convive-se com pessoas dos mais diversos credos religiosos. Elas crescem, estudam, trabalham, relacionam-se afetivamente e se divertem juntas, mas nem sempre têm conhecimento da opção religiosa de quem está ao seu lado. O ditado popular diz: "futebol, política e religião não se discute". É uma tolerância aparentada pelo desconhecimento da crença do outro. Muitos crentes ainda têm dificuldade em admitir a realidade de fé plural. Alguns tentam impor a sua religião gerando conflito. Outros são relativistas. Sem falar nos indiferentes, proselitistas, fanáticos, fundamentalistas e extremistas. Mas há aqueles que se dispõem ao diálogo aberto e sincero capaz de construir a unidade na diversidade religiosa.

Olhar com atenção para esse caminho, muito mais do que um exercício formal, é um compromisso do Batismo, que apresenta, entre outros, o significado de participar em unidade na diversidade humana. O povo do diálogo não é 
exclusividade da Igreja Católica ou dos cristãos, mas proposta aberta igualmente a todos, porque as outras igrejas e todas as pessoas devem formar o diálogo.

\section{Cultura do encontro e do diálogo}

Pela acolhida e abertura ao outro, sem abrir mão de suas concepções, identidade e certezas é que o diálogo se faz. No encontro com o outro, a partir da experiência e a perspectiva do outro, que é diferente de mim, pode-se aprender muito e enriquecer toda a Igreja e a sociedade. Porém, isso não significa perder a própria identidade porque a identidade é a contribuição da pessoa.

Aliás, é ancorado nas diferentes concepções que o diálogo acontece. Por esse motivo, as concepções, identidade e certezas do outro podem trazer fortalecimento e robustecimento da própria fé. Não se trata de sincretismo, fusão de diferentes doutrinas, nem de ecletismo, escolha do que parece melhor para um denominador comum, mas sim de uma experiência de fé entre religiões diferentes que conduza a uma reflexão interior. Afirma Britto: "é possível a emergência de uma identidade de abertura para a diferença, para a alteridade, com complexidade, mas que, no entanto, não represente algo sem lastro, sem raízes ou sem referência permanentes". ${ }^{5}$ Wolff colabora: "o diálogo promove a 'cultura do encontro' com a sociedade, com as outras Igrejas, as culturas e religiões, a fim de, a partir da própria fé, encontrar-se num projeto comum de cooperação para o bem de toda humanidade". 6

A experiência do encontro envolve diferenças e se cresce com elas. O outro, o diferente, tem o seu lugar. Encontrar-se significa possibilidade de mútuo respeito, entendimento e convivência. A concepção é de uma cultura que "está embasada num processo de construção coletivo e solidário, de esforço mútuo, garantido pelo princípio fundamental de igualdade". ${ }^{7}$

A este modo de pensar a cultura, o Papa Francisco chama de cultura do encontro, que leva em conta a diversidade e a pluralidade, requer que estejamos dispostos não só a dar, mas também a receber de outros. O início da cultura do encontro está no encontro com Deus, Pai das Misericórdias, revelado por Jesus, fonte de toda ação evangelizadora da Igreja. Todo cristão experimenta que o Senhor tomou a iniciativa e precedeu-o no amor, e este amor lhe devolve o sentido da vida (1Jo 4,10). "Como pode conter o desejo de comunicá-lo aos outros?"8

\footnotetext{
${ }^{5}$ BRITTO, R. R., Cibercultura, p. 31.

${ }^{6}$ WOLFF, E., Igreja em diálogo, p. 24.

${ }^{7}$ BRITTO, R. R., Cibercultura, p. 52.

${ }^{8}$ EG 08.
} 
O diálogo consiste numa atitude espontânea em busca do encontro dos diferentes capaz de gerar frutos de uma experiência gratuita, generosa, onde a beleza e o encanto do outro aproxima e cativa. Por outro lado, a impressão pode ser de medo e desconfiança. A qualidade do encontro vai depender da preparação para o encontro.

O diálogo e o encontro como cultura são uma espécie de "código de conduta" para a Igreja e a sociedade, garantindo relações respeitosas, não agressivas e não proselitistas e acreditando que, à medida que se supera o espírito de competição entre as diferenças, se está superando a "cultura do conflito" entre pessoas, povos, culturas e tradições de fé. O diálogo é fruto do encontro, que conduz ao intercâmbio de dons, à cooperação e à comunhão. Isso tem implicações para a Igreja que vai ao encontro de todos e a todos valoriza em suas riquezas sociais, culturais e religiosas. Em todos vê uma expressão do Evangelho. ${ }^{9}$

A motivação e a finalidade do encontro dialogal precisam estar bem claras para evitar forçar um diálogo por causa de determinada situação particular. "É preciso querer dialogar para encontrar o modo correto de inserção no pluralismo eclesial e religioso e da exploração positiva das circunstâncias do diálogo. E isso implica a formação para o diálogo". ${ }^{10}$ Ao cristão, cabe ficar atento às necessidades e possibilidades do diálogo, isto é pré-condição para abertura ao pluralismo eclesial e religioso. Insensibilidade, neste caso, torna-se sinônimo de fechamento ao diálogo.

Dentre as diversas formas de diálogo, pode-se elencar a convivência, a ação conjunta e o diálogo teológico. Uma boa convivência entre diferentes revela que o sabor do diálogo vai depender da capacidade de relação com o diferente, atenção, respeito e acolhimento. "Na convivência, é necessário reconhecer que o outro tem direito a um espaço para a manifestação de sua identidade, suas peculiaridades e seus valores". ${ }^{11}$

Nesse contexto, é mister destacar o diálogo da colaboração, ou seja, viver e conviver num mesmo ambiente, partilhar das possibilidades e carências deste, é condição para a mútua cooperação e colaboração entre pessoas de diversas igrejas e religiões. "A finalidade é a libertação e a promoção do ser humano.

\footnotetext{
${ }^{9}$ WOLFF, E., Igreja em diálogo, p. 25-26.

${ }^{10}$ WOLFF, E., Ministros do diálogo, p. 68.

${ }^{11}$ WOLFF, E., Ministros do diálogo, p. 69.
} 
Trata-se de um diálogo de obras, de mútua cooperação em favor de um mundo melhor e mais justo". ${ }^{12}$

Assim, à medida que as religiões, entre elas o cristianismo, consigam descentrar-se de seus problemas internos e situar-se no mundo, em espírito de colaboração e diálogo, poderão encontrar o sentido mais profundo de seu ser e de sua missão. A fraternidade universal e uma humanidade "com vida em abundância" é a vocação missionária a que o cristianismo está chamado para ser sinal e sacramento, na debilidade e grandeza de sua história. ${ }^{13}$

Talvez as Igrejas e religiões, como sugestão, possam ressignificar seu atendimento e serviço aos mais empobrecidos, como característica eclesial que promove a unidade. Diante das mais diversas circunstâncias que resultam na falta de dignidade humana, pode também a Igreja, "suscitar obras destinadas ao serviço de todos, sobretudo dos pobres, tais como obras caritativas e outras semelhantes". ${ }^{14}$

Além da colaboração e da convivência, o diálogo pode se dar através dos intercâmbios teológicos. Daí surge a "necessidade de aprofundar o conhecimento dos respectivos patrimônios religiosos, base para um mútuo conhecimento e superação dos muitos preconceitos". ${ }^{15}$ Cabe, sem dúvida, aos peritos em Teologia essa árdua tarefa de "aprofundar a compreensão das respectivas heranças religiosas e destacar os valores espirituais comuns. Entre as igrejas, acentua-se a busca da unidade; entre as religiões, a cooperação". ${ }^{16} \mathrm{~A}$ abertura para expor ao outro as convicções pessoais é sinônimo de deixar-se transformar pelo outro, sem perder a identidade, diferente de converter-se à igreja ou religião do outro.

Por fim, há também o diálogo espiritual que abrange a partilha de experiências deste nível entre os interlocutores. É o nível mais profundo e elevado do diálogo, envolvendo a oração, a contemplação, a fé e o compromisso. É um olhar que vai além das diferenças, que mesmo sendo profundas, não impedem a atitude humilde de confiança e abandono a Deus.

Ora, isto porque se tem em vista que, ao invés da exclusão, o Evangelho inspira a todos os cristãos a aproximar, acolher, cooperar e conviver,

\footnotetext{
${ }^{12}$ WOLFF, E., Ministros do diálogo, p. 69-70.

${ }^{13}$ BRIGHENTI, A., A igreja perplexa, p. 125.

${ }^{14}$ WOLFF, E., Ministros do diálogo, p. 98.

${ }^{15}$ WOLFF, E., Ministros do diálogo, p. 70.

${ }^{16}$ WOLFF, E., Ministros do diálogo, p. 71.
} 
testemunhando o seguimento a Jesus Cristo, Mestre do diálogo. Logo, espera-se do ser cristão uma identidade relacional, que vai se construindo, na medida em que ele "buscar situar-se nesse contexto, discernindo o significado do pluralismo eclesial e religioso para o seu meio e as interpelações que ele apresenta para o Evangelho que ele proclama". ${ }^{17} \grave{A}$ atividade dos agentes pastorais, diante da diversidade eclesial e religiosa, se faz urgente buscar estratégias para renovar as atitudes e flexibilizar os métodos para se alcançar a unidade. "Isso implica a superação de uma identidade fechada por uma identidade plural/relacional que mostre ser [...] de flexibilidade e de tolerância, capaz do diálogo sincero e equilibrado com a alteridade religiosa". ${ }^{18}$ Esta iniciativa não significa indiferença ou atitude relativista quanto às verdades da própria fé.

A identidade do sujeito eclesial possui uma configuração relacional, que se dá com sua comunidade, na sociedade e com as diferentes tradições eclesiais e religiosas. Ele "não constrói sua identidade religiosa e ministerial de modo fechado aos grupos religiosos que não pertencem à sua tradição de fé. Ele estabelece diálogo, relação com esses grupos". ${ }^{19}$ A sua identidade é mais que confessional, é interconfessional, sendo que permanece aberto às comunidades de fé que não pertencem à sua própria comunidade. Sendo assim, nada o impede de realizar um determinado trabalho noutra Igreja, que enriqueça sua preparação recebendo algo dos membros das outras tradições religiosas e eclesiais. A partilha de saberes e a troca de experiências engrandecem o ser religioso do cristão. Se ele vier a perder sua identidade relacional será porque decidiu "fechar-se na autosuficiência, transformar a própria vida, a própria fé e a própria vocação numa mônada, construir uma identidade sem relação, subestimando o valor do outro e dificultando as possibilidades enriquecedoras de diálogo". ${ }^{20}$

Uma Igreja disposta a dialogar, a relacionar-se com o que crê diverso, transforma-se na comunidade dos reconciliados. E isso, somente é possível, quando há um ambiente de acolhimento, e, sobretudo, de perdão. O diálogo como paradigma do agir cristão possui como fim a unidade do Povo de Deus. O desejo do Pai, expresso em Jesus Cristo, é que haja um só rebanho e um só pastor. Isso não significa uniformidade de expressões religiosas.

A comunhão em torno apenas da fé, dos sacramentos e dos ministérios corre o risco de possuir sentido exclusivista, deixando à margem quem não adere explicitamente a esses elementos. Por isso é fundamental a

\footnotetext{
${ }^{17}$ WOLFF, E., Ministros do diálogo, p. 90.

${ }^{18}$ WOLFF, E., Ministros do diálogo, p. 90.

${ }^{19}$ WOLFF, E., Ministros do diálogo, p. 116.

${ }^{20}$ WOLFF, E., Ministros do diálogo, p. 91.
} 
unidade em torno das Escrituras - que a um só tempo fundamenta e transcende a expressão unidade de fé, nos sacramentos e ministérios - e a unidade no interior da vida do povo de Deus - que visa à humanidade como um todo, transcendendo as fronteiras, até das tradições religiosas. ${ }^{21}$

O desejo de unidade e de comunhão entre todos os seres humanos transcende as diversidades e pluralismos. "A Igreja recomenda a todos os seus filhos, e também a todos os homens, que superem com este espírito de família próprio dos filhos de Deus, todos os conflitos entre nações e raças". ${ }^{22}$ Permanece o convite e o desafio essencial à abertura ao outro, ao diferente, itinerário de mútua compreensão e recíproco enriquecimento. $\mathrm{O}$ encontro com o diferente exige respeito, paciência, escuta e serviço, isenção de falas normativas e imperativas que carregam imposições de suas próprias convicções.

Como descreve o Documento de Aparecida, "só a proximidade que nos faz amigos e nos permite apreciar profundamente os valores" 23 do outro, no seu hoje, com "seus legítimos desejos e seu modo próprio de viver a fé". ${ }^{24}$ A cultura do encontro prioriza o relacionamento igualitário, um espaço de crescimento e amizade que nasce da proximidade.

\section{Recuperar o projeto de Jesus}

Transcendendo suas referências doutrinais consolidadas e acolhendo as verdades externas, a Igreja em diálogo interno deve lançar-se para uma tarefa mais difícil e ampla de dialogar com o mundo presente. Um exercício que exige rupturas com concepções e práticas tidas como completas e definitivas no seio da tradição católica. As diferenças teóricas e práticas construídas pelo mundo contemporâneo, comumente vistas pela Igreja como equívocos e, em muitas ocasiões condenadas, devem ser agora olhadas de frente e atualizadas.

A proposta cristã baseia-se na vocação relacional do homem, que necessita do "sair de si" e ir ao encontro do "diferente de si" para sua autorrealização. Jesus Cristo falava e agia a partir da profundidade de si mesmo, no relacionamento de intimidade manifestado em sua vida num conhecimento exclusivo do Pai (Mt 11,25-27; Lc 10,21-22) e adesão profunda de si, vivida na força do Espírito, fazendo daqueles que $\mathrm{O}$ encontravam participantes de seu conhecimento (Mt 13,11).

${ }^{21}$ WOLFF, E., Ministros do diálogo, p. 97-98.

22 GS 42.

${ }^{23}$ DAp 398.

${ }^{24}$ DAp 398. 
Ao longo de sua missão, Jesus é modelo de escuta, diálogo e anúncio, mostra ao homem a verdadeira natureza do Pai e transforma toda falsa religião na lei do amor e em atos de misericórdia. Insere-se no meio do povo, vivendo como alguém do povo, conhecia sua história, seus desafios e esperanças. Uma maneira simples de encontrar-se com aqueles de seu tempo, proporcionando atenta escuta aos pedidos dos leprosos, dos cegos, da mulher que sofria do fluxo de sangue, daqueles que estavam ao seu redor. Ao se encontrar com os fariseus e doutores da Lei, dialogava sem medo dos confrontos, propondo aprimorada reflexão sobre o acolhimento e aceitação do outro, a importância da misericórdia que extingue o legalismo gerador de exclusão e sofrimento. Ele apresenta um Deus diferente, comprometido com os pobres e oprimidos, um Deus compaixão.

Jesus se revela como uma testemunha autêntica do amor infinito de Deus Pai pelos homens (Jo 8,40). A partir do diálogo e do encontro com o outro, Ele se dá a conhecer com suas próprias atitudes, os verdadeiros valores da vida. É através do diálogo e do encontro com o outro que a mensagem da Boa Nova de Jesus se torna mais conhecida, autêntica e sempre nova. Jesus é o referencial na busca de estabelecer o diálogo no encontro com o outro, sobretudo para os que recebem a alcunha de cristãos, seus discípulos.

Sem dúvidas, Jesus não abre mão da sua identidade, da sua missão, não apresenta uma verdade relativa, nem tem medo de confrontos e da verdade do outro. Ele expõe a verdade do Pai, o anúncio do Reino, sem imposição, apenas propõe o caminho de uma nova vida.

Jesus é o mestre itinerante que ensina tanto com suas palavras, como com seu exemplo. Ele elaborou um plano progressivo, com seus objetivos concretos e uma metodologia definida. Sua missão é salvar o homem de qualquer tempo ou latitude, Ele sintetiza sua missão em cinco pontos quando na sinagoga de Nazaré apresenta o seu plano de trabalho: $\mathrm{O}$ Espírito do Senhor está sobre mim, porque me ungiu e enviou-me para: anunciar a Boa Nova aos pobres, proclamar a libertação aos cativos, dar vista aos cegos, por em liberdade os oprimidos e proclamar o ano da graça do Senhor (Lc 4,1-19). Sua meta é instaurar o Reino. Jesus percorria as cidades, ensinava nas sinagogas, curava enfermos e sua pregação central era apresentar o Reino do Pai. ${ }^{25}$

Tal como na proposta essencial deixada por Jesus no Evangelho, que consiste no amor a Deus e ao próximo, o Reino de Deus que Jesus apresenta é

${ }^{25}$ FLORES, J. H. P., Formação de discípulos, p. 16. 
uma realidade comunitária que se consolida na dinâmica do amor recíproco e da vivência de um nós, a partir do reconhecimento de um tu personificado na figura do próximo de quem fala o Evangelho. Depois do Concílio Vaticano II, Paulo VI, na Evangelii Nuntiandi, fez esta afirmação:

Como evangelizador, Cristo anuncia em primeiro lugar um reino, o reino de Deus, de tal maneira importante que, em comparação com ele, tudo o mais passa a ser "o resto", que é "dado por acréscimo". Só o reino, por conseguinte, é absoluto, e faz com que se torne relativo tudo o mais que não se identifica com ele. ${ }^{26}$

A Igreja não pode renovar-se a partir da sua raiz se não descobre o tesouro do Reino de Deus. Não é o mesmo chamar os cristãos a colaborar com Deus no seu grande projeto de fazer um mundo mais humano que viver distraídos em práticas e costumes que fazem esquecer o verdadeiro núcleo do Evangelho. Ora, se esta é a fé da Igreja, por que há cristãos que nem sequer ouviram falar desse projeto que Jesus chamava Reino de Deus? Porque não sabem que a paixão que animou toda a vida de Jesus, a razão de ser e o objetivo de toda a sua atuação, foi de anunciar e promover esse projeto humanizador do Pai. Seguramente, a decisão mais importante que se tem de tomar hoje na Igreja é a de recuperar o projeto do Reino de Deus com alegria e entusiasmo.

O Papa Francisco chama a uma conversão radical para se voltar a Jesus Cristo, à fonte, e recuperar a frescura original do Evangelho:

Jesus Cristo pode romper também os esquemas enfadonhos em que pretendemos aprisioná-Lo, e surpreende-nos com a sua constante criatividade divina. Sempre que procuramos voltar à fonte e recuperar o frescor original do Evangelho, despontam novas estradas, métodos criativos, outras formas de expressão, sinais mais eloquentes, palavras cheias de renovado significado para o mundo atual. ${ }^{27}$

O apelo do Papa concretiza-se no objetivo primordial. A conversão que se tem de promover consiste simplesmente em voltar a Jesus. França Miranda expõe:

O cristianismo deve recuperar a novidade própria do evento Jesus Cristo. Pois o inaudito de sua proclamação e o inédito de suas ações acabaram no curso dos séculos soterradas por doutrinas, normas, instituições que,

\footnotetext{
${ }^{26}$ EN 08.

${ }^{27} \mathrm{EG} 11$.
} 
procurando estar a serviço desse evento primeiro, terminaram por ocultálo. Enunciados herméticos, representações infantis, inflação de preceitos, pacote de certezas, afastam nossos contemporâneos da fé cristã. Mas, ao contrário, que entusiasmo provoca a vida de Jesus quando devidamente apresentada! Talvez porque esta vida nos desconcerte, e o Deus que nela se revela nos surpreenda. A ênfase numa experiência de um encontro pessoal com Jesus Cristo, suas ações e suas palavras, sempre a serviço do Reino, do cuidado contínuo pelos mais pobres e sofridos, levando ânimo e vida a todos, numa fidelidade coerente até a morte, representa, sem dúvida, uma força evangelizadora de enorme significado. É só no encontro pessoal com Jesus de Nazaré que se irá desencadear um sério compromisso com Deus e um empenho na realização de seu Reino neste mundo. ${ }^{28}$

Fazendo referência à advertência de Francisco na homilia em Santa Marta dia 23 de outubro de 2013, Pagola recorda: "“a Igreja deve levar a Jesus. Este é o centro da Igreja: levar Jesus. Se, por hipótese, uma vez acontecesse que a Igreja não levasse a Jesus, ela seria uma Igreja morta'. Se uma paróquia não leva a Jesus é uma paróquia morta". ${ }^{29} \mathrm{E}$ continua, um pouco mais adiante,

Quando afirmamos "voltar a Jesus" não estamos falando de uma atualização da Igreja, um aggiornamento ou adaptação aos tempos atuais. Algo, por outra vez, totalmente necessário. Falamos de conversão a Jesus. Voltar à fonte e origem da Igreja. O único que justifica a presença dela no mundo e na história. Voltar a Jesus é deixar que Ele seja Ele na Igreja. Deixar o Deus encarnado em Jesus ser o único deus da Igreja, o Deus amigo da vida e do ser humano. ${ }^{30}$

Responsabilidade maior aos agentes da fé cristã. Por isso, é necessário que nas paróquias, comunidades, seminários e casas de formação vejam-se claramente como há de encorajar esta conversão a Jesus Cristo. Francisco reconhece que:

Precisamos de criar espaços apropriados para motivar e sanar os agentes pastorais, "lugares onde regenerar a sua fé em Jesus crucificado e ressuscitado, onde compartilhar as próprias questões mais profundas e as preocupações quotidianas, onde discernir em profundidade e com critérios evangélicos sobre a própria existência e experiência, com o

${ }^{28}$ MIRANDA, M. F., A Reforma de Francisco, p. 163.

${ }^{29}$ PAGOLA, J. A., Recuperar o projeto de Jesus, p. 27.

${ }^{30}$ PAGOLA, J. A., Recuperar o projeto de Jesus, p. 39. 
objetivo de orientar para o bem e a beleza as próprias opções individuais e sociais". 31

O Documento de Aparecida pondera: "não se trata só de estratégias para procurar êxitos pastorais, mas da fidelidade na imitação do Mestre, sempre próximo, acessível, disponível a todos, desejoso de comunicar vida em cada região da terra". ${ }^{32}$

Neste ínterim, Pagola difunde, como caminho concreto a ser seguido, os Grupos de Jesus. O seu objetivo é viver juntos um processo individual e coletivo de conversão a Jesus aprofundando o essencial do Evangelho. É um caminho concreto para regenerar a vida dos cristãos!

\begin{abstract}
"Grupos de Jesus" é o nome de um projeto que, nestes tempos, está sendo posto em prática em diversos lugares na Espanha. Seu nascimento é fruto de uma convicção básica. A renovação evangélica da Igreja dependerá, em boa parte, do desenvolvimento de pequenos grupos e comunidades que se comprometam a atualizar hoje a experiência primeira vivida junto a Jesus por aquele primeiro grupo de discípulos e discípulas que ouviram seu chamado e o seguiram. ${ }^{33}$
\end{abstract}

Nos países europeus, vivem-se tempos decisivos para o futuro da fé. E no Brasil, em menor proporção, porém silenciosamente e com muita força, vêm a conquistar espaço. Neste momento, quando estão a acontecer mudanças socioculturais sem precedentes, a Igreja necessita de uma conversão igualmente inédita, para viver e comunicar a Boa Nova de Jesus com mais verdade e mais fidelidade à sua pessoa, à sua mensagem e ao seu projeto do Reino de Deus. Os agentes pastorais são lideranças basilares nessa missão e muitos estão comprometidos nesse caminho eclesial. Contudo, é comum ouvir lamentos sobre a falta de espírito missionário, dialogal, sendo urgente uma formação mais focada nesta urgência.

Se, com urgência, não se promover nas comunidades cristãs um clima de conversão humilde e alegre a Jesus Cristo, facilmente se verá como a fé se extinguirá aos poucos entre nós e como o cristianismo multissecular se diluirá em formas religiosas cada vez mais decadentes e sectárias, e cada vez mais afastadas do movimento de seguidores inspirado e desejado por Jesus.

\footnotetext{
${ }^{31} \mathrm{EG} 77$.

${ }^{32}$ DAp 372.

${ }^{33}$ PAGOLA, J. A., Voltar a Jesus, p. 93.
} 


\section{Redescobrir o Concílio Vaticano II}

Com a leitura, aprofundamento e a prática dos documentos do Concílio Vaticano II (1962-1965), o mais ecumênico de todos, se redescobre a beleza de ser a Igreja que Jesus formou para evangelizar o mundo. O então Papa João Paulo II, no limiar do terceiro milênio, na Carta Apostólica Novo Millennio Ineunte, escreveu:

Quanta riqueza, amados irmãos e irmãs, nas diretrizes que o Concílio Vaticano II nos deu! [...] À medida que passam os anos, aqueles textos não perdem o seu valor nem a sua beleza. É necessário fazê-los ler de forma tal que possam ser conhecidos e assimilados como textos qualificados e normativos do Magistério, no âmbito da Tradição da Igreja [...] sinto ainda mais intensamente o dever de indicar o Concílio como a grande graça de que beneficiou a Igreja no século $X X$ : nele se encontra uma bússola segura para nos orientar no caminho do século que começa. ${ }^{34}$

O Concílio Vaticano II inaugurou uma era de renovação da Igreja ao colocá-la em diálogo permanente com o mundo presente. Simbolizou a abertura da Igreja Católica frente ao mundo moderno. Inaugurou-se uma nova doutrina sobre o mundo e sobre a Igreja, considerada sinal de salvação para a humanidade. Reconhecer a verdade dentro das ciências e dialogar com elas, bem como servir ao ser humano, propondo um diálogo respeitoso e construtivo é tarefa da Igreja. Houve renovação nas práticas pastorais, reflexão teológica, renovação litúrgica, diálogo com diferentes culturas, comprometimento com os pobres, diálogo ecumênico e interreligioso, doutrina social da Igreja, abertura aos ministérios leigos, etc. A Igreja passa a esforçar-se para compreender e assimilar a realidade, por fazer dos cristãos sujeitos no mundo, buscando a verdade e construindo a fraternidade universal. Para isso, exige-se libertação do medo das mudanças e do diferente, a perda de privilégios e a coragem de enfrentar os desafios.

A Igreja no Brasil, através de seus pastores, nas diretrizes gerais da sua ação evangelizadora, sempre apresenta o diálogo como uma das exigências da evangelização. Pode-se definir o período que se seguiu imediatamente ao Concílio como época do diálogo. O clima de esperança que o evento conciliar suscitou dentro e fora da Igreja foi capaz de despertar no mundo a certeza de que não há outro caminho possível para uma convivência pacífica a fim de

${ }^{34}$ NMI 57. 
construir um futuro para a humanidade, a não ser a atitude do diálogo entre as pessoas, as Igrejas, as religiões e as culturas.

O Papa João XXIII, ao convocar o Concílio, fez uma leitura da realidade de sua época e cunhou a expressão aggiornamento. É um termo italiano, que significa atualização, renovação, mudança. Esta palavra foi a orientação chave dada como objetivo para o Concílio Vaticano II.

O aggiornamento para adequar a Igreja aos tempos atuais não deveria significar a mera adaptação à relações mutáveis, mas sim abertura ao mundo moderno. O aggiornamento da Igreja, que era o objetivo do Concilio, não se verificou através da ruptura com a tradição, nem com a adaptação a um ambiente transformado; deu-se sobretudo de um aggiornamento que entrelaçou as tradições mais antigas, em parte esquecidas, com o tempo presente". ${ }^{35}$

A Constituição conciliar Sacrosanctum Concilium resume o espírito do aggiornamento da seguinte maneira: "fomentar a vida cristã entre os fiéis, adaptar melhor às necessidades do nosso tempo as instituições susceptíveis de mudança, promover tudo o que pode ajudar à união de todos os crentes em Cristo, e fortalecer o que pode contribuir para chamar a todos ao seio da Igreja" ${ }^{36}$

Apesar de seus textos não manifestarem explicitamente, o Vaticano II criou um novo consenso, um novo relacionamento, um novo modo de ser na Igreja. Porém, na atualidade há uma controvérsia sobre os resultados deste Concílio. Alguns acham que foi um acontecimento acidental e pouco feliz, não lhe reconhecem nenhum efeito positivo e atribuem-lhe muitos efeitos negativos.

O Concílio não causou uma ruptura na tradição da fé da Igreja. Não se pode separar o Concílio Vaticano II dos outros concílios precedentes e torná-lo como um super-concílio, por exemplo. Não significa uma hermenêutica de ruptura com os princípios, com os valores da tradição até então guardados no depositum fidei (tradição da fé). Os padres conciliares não queriam criar uma nova igreja, mas uma igreja renovada. A Igreja não pode ser reinventada negligenciando-se a doutrina, a tradição, os dogmas e os costumes. A revelação de Deus não se inventa, mas se atualiza de acordo com os novos desafios. Não se pode criar outro credo, mas renovar os princípios da fé verdadeiramente conforme as novas necessidades e emergências atuais.

${ }^{35}$ HOPING, H. A., Constituição Sacrosanctum Concilium, p. 99-100.

${ }^{36} \mathrm{SC} 1$. 
As orientações do Concílio foram providenciais e eram urgentes. Já não se podia esperar mais! Em termos de Igreja Católica, o cristianismo tem um importante papel para o futuro em relação ao Concílio Vaticano II. "O Concílio é uma tarefa inconclusa no interior da Igreja". ${ }^{37}$ A sua recepção está por fazer em grande parte. É uma obra gigantesca que ainda necessita de mais tempo para firmar-se na vida da Igreja. Inúmeros são os pontos do Concílio Vaticano II cuja recepção está ainda muito deficiente.

O Papa Francisco toma o apelo feito pelo Concílio como ponto de partida para o impulso renovador que quer imprimir à Igreja. São estas as suas palavras: "O Concílio Vaticano II apresentou a conversão eclesial como a abertura a uma reforma permanente de si mesma por fidelidade a Jesus Cristo". ${ }^{38}$ Os documentos do Concílio contêm uma riqueza para a formação. "O primeiro desafio da formação hoje é, parece-me, levar a sério o Concílio. Antes de sonhar com o Vaticano III, ou de ceder à tentação de voltar ao Vaticano I, realizemos o Vaticano II". ${ }^{39}$

Embora tenha um caráter especificamente pastoral, o Concílio Vaticano II não deixou de fazer uma síntese teológica, sobretudo nas duas grandes Constituições Dogmáticas Dei Verbum (1965) e Lumen Gentium (1964). Quase ao seu findar, foi promulgado pelo Papa Paulo VI um documento conciliar que marcou definitivamente a história da Igreja Católica Romana e sua relação com as demais religiões não-cristãs. Trata-se da Declaração Nostra Aetate sobre a relação da Igreja com as religiões não-cristãs, datada do dia 28 de outubro de 1965. Na Declaração, a Igreja Católica "exorta seus filhos ao diálogo e à colaboração com os seguidores das outras religiões, [...] reconhecendo, servindo e promovendo os bens espirituais e morais assim como os valores socioculturais presentes nelas". ${ }^{40} \mathrm{O}$ diálogo com os demais cristãos já fora abordado no importante Decreto Conciliar Unitatis Redintegratio, sobre o Ecumenismo, de 1964.

Passos, no verbete "Diálogo" do Dicionário do Concílio Vaticano II, afirma:

A própria intencionalidade do Concílio, desde a convocação da parte do Papa João XXIII, focada sempre no aggiornamento, até a aprovação dos Documentos finais, adota o diálogo como caminho sempre mais

\footnotetext{
${ }^{37}$ LIBANIO, J. B., Olhando para o futuro, p. 238.

${ }^{38}$ EG 26.

${ }^{39}$ ANTONIAZZI, A., A formação presbiteral no contexto atual, p. 32.

${ }^{40}$ NA 2.
} 
consciente, na medida em que a Igreja ali presente dá a si mesma o desafio de discernir e acolher o mundo moderno. ${ }^{41}$

O diálogo com as demais religiões passou a ter um valor normativo na vida da Igreja e em suas reflexões teológicas. Outros documentos seguiram esta importante Declaração, desenvolvendo, complementando e relacionando a ideia do diálogo interreligioso com outras áreas da Igreja, em especial com o anúncio evangelizador, onde pareceria haver uma potencial tensão. Poderíamos nomear aqui, apenas para relacionar alguns dos principais, a Declaração Dignitatis Humanae sobre a Liberdade Religiosa, um documento conciliar, de 7 de dezembro de 1965; o documento A Igreja e as outras Religiões: Diálogo e Missão, do então Secretariado para os Não-Cristãos, hoje Pontifício Conselho para o Diálogo Interreligioso, de 10 de junho de 1984; e o documento Diálogo e Anúncio, do Pontifício Conselho para o Diálogo Interreligioso, de 19 de maio de 1991; entre outros.

O Vaticano II não somente falou sobre o diálogo, mas iniciou um diálogo com o mundo, com as outras confissões cristãs e com as religiões não-cristãs. Levou à fundação de organismos novos a nível universal, nacional, diocesano, paroquial em vista do diálogo com todos os homens. Os católicos já não podem compreender uma prática eclesial que não esteja baseada num diálogo. Indignam-se quando certos membros da Igreja não aceitam o diálogo: essa reação espontânea mostra o alcance da nova mentalidade conciliar.

A acolhida da realidade em sua diversidade cultural e religiosa exige da Igreja Católica novo posicionamento dialogal, caminho por excelência para a solução dos principais problemas da humanidade e da própria Igreja com seus membros. Propor-se a dialogar, consiste, acima de tudo, em " "voltar-se' para o mundo com a finalidade de contribuir humildemente na solução dos problemas e servir a toda a humanidade; é uma Igreja que abandona a posição arrogante de dona da verdade e escolhe compreender positivamente as novas realidades". ${ }^{42}$

É preciso que os valores pastorais do Concílio Vaticano II sejam difundidos e afirmados de forma consistente, devem servir como base e estar presentes na formação eclesial, principalmente os princípios-chave salientados no que se refere ao diálogo, consenso, subsidiariedade e compromisso ecumênico e interreligioso. Precisamos aprender a lição deste Concílio!

${ }^{41}$ PASSOS, J. D., Diálogo, p. 266-267.

42 SANCHEZ, W. L., Vaticano II e o diálogo inter-religioso, p. 19. 
Situação contraditória é a de que inúmeros cristãos estão imersos na realidade da resistência em admitir o pluralismo religioso e eclesial; da falta de aprofundamento no conhecimento provocando questionamentos, tanto explícitos, como velados; de atitudes de fechamento, intolerância, indiferentismo, relativismo, oscilando entre absolutização de posições e sincretismo acentuado; e com as motivações para o debate, geralmente frágeis, desenvolvendo, principalmente a intolerância religiosa. Diante deste contexto, embora se tenha observado muitos avanços e progressos em relação à diversidade, ao pluralismo e a consequente e inevitável relação ecumênica e interreligiosa entre a Igreja Católica com as outras Igrejas e religiões, há muito que avançar, por parte dos agentes pastorais, ministros eclesiais, ordenados ou não. Conforme o Documento de Aparecida,

Em nosso contexto, o surgimento de novos grupos religiosos, além da tendência a confundir o ecumenismo com o diálogo interreligioso, tem causado obstáculos na conquista de maiores frutos no diálogo ecumênico. Por isso mesmo, incentivamos os ministros ordenados, aos leigos e à vida consagrada a participarem de organismos ecumênicos com cuidadosa preparação e esmerado seguimento dos pastores, e realizarem ações conjuntas nos diversos campos da vida eclesial, pastoral e social. $\mathrm{Na}$ verdade, o contato ecumênico favorece a estima recíproca, convoca à escuta comum da palavra de Deus e chama à conversão aqueles que se declaram discípulos e missionários de Jesus Cristo. Esperamos que a promoção da unidade dos cristãos, assumida pelas Conferências Episcopais, se consolide e frutifique sob a luz do Espírito Santo. ${ }^{43}$

Apesar da importância dada à relação dialógica com as religiões, por parte da Igreja Católica, Wolff constata que há um "desconhecimento que a maioria das lideranças eclesiásticas, dos professores de teologia, formadores/as e seminaristas possuem das igrejas e religiões". ${ }^{44}$

Segundo Wolff, o diálogo interreligioso e intereclesial não está encontrando espaço na formação dos agentes de pastoral em geral, sobretudo dos ministros ordenados. Dentre os principais fatores causadores dessa realidade citase, "o conteúdo formativo das casas de formação possui preocupações exclusivas ad intra à Igreja e ao instituto religioso/diocese a que pertencem, considerando o diálogo intereclesial e inter-religioso como se fossem algo ad extra" ${ }^{45}$ A

\footnotetext{
${ }^{43}$ DAp 232.

${ }^{44}$ WOLFF, E., Ministros do diálogo, p. 09.

${ }^{45}$ WOLFF, E., Ministros do diálogo, p. 10.
} 
formação para o diálogo não deve ser deixada para depois, é prioridade formativa para os agentes de pastorais, sobretudo os padres. A carência na formação para o diálogo ecumênico e interreligioso "tolhe à Igreja a possibilidade de manifestar uma das suas dimensões fundamentais - a abertura ao diálogo com outras expressões da relação com o divino, no interior do pluralismo eclesial e religioso do nosso tempo". " O diálogo é elemento estrutural do ser eclesial. Sem abertura para o diálogo, o agente pastoral não aplicará as orientações do Magistério sobre as relações com as Igrejas e as religiões.

A formação cristã pressupõe uma atitude dialógica, é teoria, mas também é prática. É conhecimento que se torna comportamento. É personalidade ecumênica, baseada no diálogo e na tolerância, exigida dos ministros eclesiais. Tal iniciativa se concretiza na conversão do coração.

$\mathrm{O}$ processo formativo tem por objetivo despertar no agente pastoral a capacidade de sensibilizar-se diante do diferente, seu relacionamento respeitoso e compreensivo com o outro, revela a sensibilidade da Igreja frente ao diferente, mesmo que esse pense, aja e creia de modo diverso. Do respeito, nasce a humildade em relação à verdade. É preciso perceber e crer que não se possui toda a verdade.

Para Wolff, nos meios formativos há muitas atitudes fixas, unilaterais e defensivas, em relação às igrejas e religiões. Posições absolutistas vão contra a implementação do pluralismo eclesial e religioso. "Deste modo, a formação e atuação dos ministros da Igreja assumem ares apologéticos, desafiando as outras tradições eclesiais e religiosas, até procurando apresentá-las como falsas, em vista da legitimação de uma única tradição de fé". ${ }^{47}$

O desejável é que a formação cristã aconteça sempre numa perspectiva de olhar a realidade na sua diversidade, buscando confrontar teoria e prática, espiritualidade e vivência. "O desafio fundamental é fazer com que a orientação vocacional dos agentes de pastoral [...] não aconteça de modo isolado do contexto do pluralismo eclesial e religioso, presente na sociedade na qual se encontram". 48

A renovação da Igreja pretendida e orientada pelo Vaticano II estará sempre em curso quando o diálogo, a misericórdia e o serviço forem as atitudes constantes que rejam todos os ministérios que compõem a Igreja, os ordenados e os não ordenados, enfim, todos os cristãos.

\footnotetext{
${ }^{46}$ WOLFF, E., Ministros do diálogo, p. 15-16.

${ }^{47}$ WOLFF, E., Ministros do diálogo, p. 20.

${ }^{48}$ WOLFF, E., Ministros do diálogo, p. 23.
} 


\section{Conclusão}

O tema do diálogo interpela os cristãos deste tempo a terem consciência de que não vivem sozinhos e que este mundo exige deles uma responsabilidade com o outro. Para dialogar é importante estar disposto a ouvir o outro verdadeiramente, tentar construir um entendimento comum, verificar pontos parecidos nas várias ideias apresentadas, respeitar o ponto de vista do outro, tratar as opiniões diferentes da sua como oportunidades de conhecimento e crescimento e não como opiniões a serem combatidas.

O diálogo não é somente feito por discursos, ainda que constitua uma mediação necessária; exige de todos o testemunho verdadeiro e sincero, quando a vivência fala antes da palavra e convida para a vida em comunhão. É preciso recuperar o sentido humano do diálogo, como práxis da vida cristã, como condição de aproximação e identificação com o outro, a exemplo do Bom Samaritano (Lc 10,29-37), pois na sociedade crescem suas capacidades de manejo, de criação instrumental e tecnológica, mas o homem, em contrapartida, parece perder a disponibilidade de relacionar-se e conviver de forma solidária com os seus semelhantes.

Os cristãos são chamados a dialogar com todos para descobrir a verdade e construir a unidade desejada por Deus na vivência da caridade. A razão de ser do diálogo e sua finalidade é a vivência do amor. Como tradução do amor que coloca em relação de respeito e conhecimento mútuo todas as diferenças, o diálogo permanecerá como grande regra para a Igreja e seus membros. Desse amor a Igreja é sinal e promotora. O Decreto Conciliar Christus Dominus, deixa isto bem claro:

Como é dever da Igreja estabelecer o diálogo com a sociedade humana na qual vive, [...] este diálogo de salvação se distinga pela perspicácia da palavra e simultaneamente pela humildade e afabilidade, e ao mesmo tempo pela devida prudência unida contudo à confiança, porquanto esta, ao favorecer a amizade, se destina a unir os ânimos. ${ }^{49}$

A missão dos cristãos torna-se cada vez mais desafiadora, convidada a rever os seus paradigmas, aprofundar e empenhar-se em favor do diálogo e da cultura do encontro, ou seja, conforme diz o Papa Francisco, "aceitar os outros, na sua maneira diferente de ser, de pensar e de se exprimir". ${ }^{50}$ Seu exemplo

\footnotetext{
${ }^{49} \mathrm{CD} 13$.

${ }^{50} \mathrm{EG} 250$.
} 
missionário é Jesus, aquele que não se negava a ouvir o outro, sem medo dos confrontos e da verdade.

O diálogo não pode constituir unicamente uma estratégia pastoral da Igreja Católica com a intenção de reconciliar-se com o homem de seu tempo ou mesmo com as demais profissões religiosas diferentes da sua. Se no propósito da renovação da Igreja empreendido pelo Concílio Vaticano II pôde existir tal dimensão como método prático, ela não é, contudo, o que o define fundamentalmente. Neste sentido também o Documento Diálogo e Missão descreve que a Igreja se torna, por assim dizer, sujeito de diálogo e que este não se resume só no "colóquio, mas também o conjunto das relações interreligiosas, positivas e construtivas, com pessoas e comunidades de outras confissões religiosas, para um mútuo conhecimento e um recíproco enriquecimento". ${ }^{51}$ A Igreja quer ser sinal vivo, ser servidora fiel do plano salvífico de Deus que chama todos para comunhão consigo.

Enfim, faz-se necessário aproximar-se das diversas realidades humanas, conhecê-las e acolhê-las. Vivendo a alteridade, construir uma sólida hermenêutica isenta de fundamentalismos. Sem riscos, a mensagem cristã pode ser autêntica se viver a mensagem transmitida por Jesus: a misericórdia, que gera espaço de verdade, diálogo e acolhimento.

\section{Referências bibliográficas}

ANTONIAZZI, A. A formação presbiteral no contexto atual. In: CNBB. Metodologia do processo formativo: a formação presbiteral da Igreja no Brasil. São Paulo: Paulinas, 2001.

BÍBLIA de Jerusalém. Nova ed. rev. e ampl. 2. impr. São Paulo: Paulus, 2003.

BRIGHENTI, A. A igreja perplexa: a novas perguntas, novas respostas. São Paulo: Paulinas, 2004. (Coleção Soter São Paulo).

BRITTO, R. R. Cibercultura: sob o olhar dos estudos culturais. São Paulo: Paulinas, 2009.

CELAM. Documento de Aparecida. Texto conclusivo da V Conferência Geral do Episcopado Latino-Americano e do Caribe. Brasília: CNBB; São Paulo: Paulus / Paulinas, 2007.

${ }^{51}$ SECRETARIADO PARA OS NÃO-CRISTÃOS, A Igreja e as outras religiões, p. 03. 
CONCÍLIO VATICANO II. Constituição Pastoral Gaudium et Spes. In: COMPÊNDIO DO CONCÍLIO VATICANO II. Constituições, decretos, declarações. Petrópolis, Vozes, 1991. p. 141-256.

CONCÍLIO VATICANO II. Constituição Sacrosanctum Concilium. In: COMPÊNDIO DO CONCÍLIO VATICANO II. Constituições, decretos, declarações. Petrópolis, Vozes, 1991. p. 257-306.

CONCÍLIO VATICANO II. Declaração Nostra Aetate. In: COMPÊNDIO DO CONCÍLIO VATICANO II. Constituições, decretos, declarações. Petrópolis, Vozes, 1991. p. 617-625.

CONCÍLIO VATICANO II. Decreto Christus Dominus. In: COMPÊNDIO DO CONCÍLIO VATICANO II. Constituições, decretos, declarações. Petrópolis, Vozes, 1991. p. 401-436.

DUROZOI, G.; ROUSSEL, A. Diálogo. In: DUROZOI, G.; ROUSSEL, A. Dicionário de filosofia. 5.ed. Campinas: Papirus, 2005. p. 135-136.

FLORES, J. H. P. Formação de discípulos. São Paulo: Loyola, 1996.

FRANCISCO, PP. Carta Encíclica Evangelii Gaudium: sobre o anúncio do evangelho no mundo atual. São Paulo: Loyola, 2013.

HOPING, H. A. Constituição Sacrosanctum Concilium. In: GERALDO, B. H.; MIGUEL, S. A. (Orgs.). As Constituições do Vaticano II, Ontem e Hoje. Brasília: CNBB, 2015.

JOÃO PAULO II, PP. Carta Apostólica Novo Millennio Ineunte. São Paulo: Paulus / Loyola, 2003.

LIBANIO, J. B. Olhando para o futuro: prospectivas teológicas e pastorais do cristianismo na América Latina. São Paulo: Loyola, 2003.

MIRANDA, M. F. A reforma de Francisco: fundamentos teológicos. São Paulo: paulinas, 2017.

PAGOLA, J. A. Voltar a Jesus: para a renovação das paróquias e comunidades. Petrópolis: Vozes, 2016.

PAGOLA, J. A. Recuperar o projeto de Jesus. Petrópolis: Vozes, 2019.

PASSOS, J. D. Diálogo. In: PASSOS, J. D.; SANCHEZ, W. L. (Coords.). Dicionário do Concílio Vaticano II. São Paulo: Paulus, 2015. p. 266-273. 
PAULO VI, PP. Exortação Apostólica Evangelii nuntiandi: sobre a evangelização no mundo contemporâneo. São Paulo: Paulinas, 2012. (A voz do Papa, 85).

SANCHEZ, W. L. Vaticano II e o diálogo inter-religioso. São Paulo: Paulus, 2015. SECRETARIADO PARA OS NÃO-CRISTÃOS. A igreja e as outras religiões: diálogo e missão. São Paulo: Paulinas, 2010.

TEIXEIRA, Faustino; DIAS, Zwinglio Mota. Ecumenismo e diálogo interreligioso: a arte do possível. Aparecida: Santuário, 2008.

WOLFF, E. Ministros do diálogo: o diálogo ecumênico e inter-religioso na formação presbiteral. São Paulo: Paulus, 2004.

WOLFF, E. Igreja em diálogo. São Paulo: Paulinas, 2018.

\section{Éverton Aparecido da Silva}

Mestre em Teologia pela Pontifícia Universidade Católica do Paraná Docente da Faculdade João Paulo II Marília / SP - Brasil E-mail: evertonaparecidodasilva@yahoo.com.br

Recebido em: 03/08/2020

Aprovado em: 04/08/2021 